\title{
The financial burden of sickle cell disease on households in Ekiti, Southwest Nigeria
}

This article was published in the following Dove Press journal:

ClinicoEconomics and Outcomes Research

4 November 2015

Number of times this article has been viewed

Oladele Simeon Olatunya ${ }^{1,3}$

Ezra Olatunde Ogundare ${ }^{1,3}$ Joseph Olusesan Fadare ${ }^{2}$ Isaac Oludare Oluwayemi ${ }^{1,3}$ Oyinkansola Tolulope Agaja ${ }^{3}$ Babajide Samson Adeyefa ${ }^{3}$ Odunayo Aderiye ${ }^{3}$

'Department of Paediatrics, Ekiti State University, Ado Ekiti, Nigeria; ${ }^{2}$ Department of Clinical Pharmacology, Ekiti State University, Ado Ekiti, Nigeria; ${ }^{3}$ Department of Paediatrics, Ekiti State University Teaching Hospital, Ado Ekiti, Nigeria
Correspondence: Oladele Simeon Olatunya Department of Paediatrics, Ekiti State University/Teaching Hospital, PO Box 2267, Ado Ekiti, Nigeria Tel +23480386I 7705

Email ladeletunya@yahoo.com
Background: Studies on economic impact of sickle cell disease (SCD) are scanty despite its being common among children in developing countries who are mostly Africans.

Objective: To determine the financial burden of SCD on households in Ado Ekiti, Southwest Nigeria.

Methods: A longitudinal and descriptive study of household expenditures on care of 111 children with SCD managed at the pediatric hematology unit of the Ekiti State University Teaching Hospital was conducted between January and December 2014.

Results: There were 64 male and 47 female children involved, aged between 15 and 180 months. They were from 111 households, out of which only eight (7.2\%) were enrolled under the National Health Insurance Scheme. The number of admissions and outpatients' consultations ranged from 1 to 5 and 1 to 10 per child, respectively. Malaria, vaso-occlusive crisis, and severe anemia were the leading comorbidities. The monthly household income ranged between $\$ 12,500$ and \#330,000 (US\$76 and US\$2,000) with a median of \$55,000 (US\$333), and health expenditure ranged between $\$ 2,500$ and $\$ 215,000$ (US\$15 and US\$1,303) with a mean of $\$ 39,554 \pm 35,479$

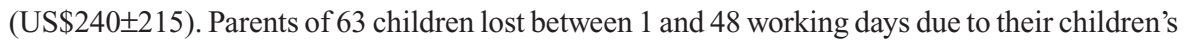
ill health. Parents of 23 children took loans ranging between $\$ 6,500$ and $\$ 150,000$ (US\$39 and US\$909) to offset hospital bills. The percentage of family income spent as health expenditure on each child ranged from 0.38 to 34.4. Catastrophic health expenditure (when the health expenditure $>10 \%$ of family income) occurred in $23(20.7 \%)$ households. Parents who took loan to offset hospital bills, low social class, and patients who took ill during the study period significantly had higher odds for catastrophic health expenditure ( $95 \%$ confidence interval [CI] 5.399-87.176, $P=0.000 ; 95 \%$ CI 2.322-47.310, $P=0.002$; and 95\% CI 1.128-29.694, $P=0.035$, respectively).

Conclusion: SCD poses enormous financial burden on parents and households.

Keywords: sickle cell disease, family income, health expenditure, financial catastrophe, Nigeria

\section{Introduction}

Sickle cell disease (SCD) is the commonest inherited disorder of hemoglobin in children resulting from the inheritance of abnormal hemoglobin genes from both parents. ${ }^{1}$ It is estimated that between 150,000 and 300,000 children are born every year with the condition in Africa. ${ }^{2}$ Nigeria, by her sheer huge size, is the country with the highest burden of the disease where $\sim 2 \%$ of all newborns are born with the disorder. ${ }^{3}$ The course of the disease varies widely with some children exhibiting severe manifestations requiring frequent hospital visits and admissions..$^{2-5}$ The condition poses enormous stress and financial burden on the parents of children with the disease who are usually 
the primary caregivers in most instances. ${ }^{6}$ It could therefore be speculated that SCD has the tendency to greatly deplete the finances of households in developing countries where there is high level of poverty and inequitable distribution of wealth and resources. ${ }^{6-9}$

Health care in most developing countries is mostly funded through out-of-pocket spending (OOPS). ${ }^{8}$ In Nigeria, OOPS for health care is the commonest form of health care financing, and it accounts for between $70 \%$ and $95 \%$ of the total monies spent on health care..$^{6,7,10-13}$ This method of health care financing does not offer any financial risk protection and may lead to financial catastrophe for households. ${ }^{8,14,15}$ Catastrophic health expenditure (CHE) represents the situation in which an individual or household spending on maintaining health compromises other basic needs, and/or incurs debts, sells assets, and becomes impoverished..$^{8,14-17}$ The widely held consensus regarding the cut-off to describe CHE is spending $>10 \%$ of total household income or $>40 \%$ of nonfood income to maintain health. ${ }^{7,16}$

Although some studies on household health expenditures exist in Nigeria, ${ }^{6,710-12}$ only a few were on $\mathrm{SCD}^{6}$ despite its chronic nature and high prevalence in the country. ${ }^{3}$ Examining the financial burden of SCD on households will help to guide policy makers define appropriate strategies to offset the burden and guide health care providers in their choice of cost-effective measures in taking care of children with the disease condition. It will also help the households to plan for the health care needs of their wards with SCD. This study set out to determine the financial impact of SCD on parents in our location of practice with the aim of ascertaining the proportion of families tipped into financial catastrophe due to care for children with SCD. It also identified household coping strategies for and risks of CHE. Recommendations were made to stakeholders on how to achieve effective health care financing and avoid CHEs while caring for children with the disease condition.

\section{Materials and methods Study design and setting}

This was a prospective cross-sectional descriptive study of children with SCD and their parents' health care finances to maintain the children's health. The children were those being managed at the pediatric hematology unit of the Ekiti State University Teaching Hospital (EKSUTH), Ado Ekiti, Southwest Nigeria. The study was conducted between January and December 2014.

The EKSUTH is a tertiary public health facility providing health care to citizens of Ekiti State. It serves as a referral center to other hospitals within the state and other adjoining states like Osun, Ondo, Kwara, and Kogi that share borders with Ekiti State. The hospital is located in Ado Ekiti which doubles as both the headquarters of Ado Local Government Area and the state capital. The city is mainly populated by the Yorubas of the southwestern part of Nigeria and has a population of approximately 308,621 inhabitants. ${ }^{18}$ Agriculture is the main occupation of the people of Ekiti, and it is the major source of income for many in the state. Agriculture provides income and employment for $>75 \%$ of the population of Ekiti State. Some of Ekiti's agricultural produce are as follows: cash crops such as cocoa, oil palm, kola nut, plantain, bananas, cashew, citrus, and timber; and arable/food crops such as rice, yam, cassava, maize, and cowpea. Like a typical rural Nigerian setting, there are also a handful of civil servants, artisans, and small-business owners in Ekiti, and the minimum wage for the civil servants is similar to that of other states in Nigeria. ${ }^{19}$

The pediatric hematology unit runs weekly specialist clinics where SCD patients and other pediatric hematology cases are referred and seen. In addition, the unit also admits and treats other pediatric hematological conditions alongside SCD patients. The unit is headed by a consultant pediatrician supported by the complements of residents, nurses, and other medical staffs. There is no free treatment for patients seeking medical care at the facility as they have to pay their medical bills through self-financing, except those who are enrolled in the National Health Insurance Scheme (NHIS) in which case a partial subsidy is given. ${ }^{20}$ The minimum monthly wage for civil servants is similar to the national average of \#18,000 (US\$109). ${ }^{21}$ The average exchange rate of the Nigerian currency (Naira) to the US dollar was 165 Naira to 1 USD during the study period. ${ }^{22}$

\section{Participants' selection}

All the children being managed for SCD at the pediatric hematology unit of the hospital constituted the sample frame, out of which only those whose parents gave consent to participate were recruited into the study consecutively. Newly diagnosed cases of SCD as well as those who were yet to attend the pediatric hematology unit for up to 1 year by the end of December 2014 were excluded. Those whose caregivers were not the parents or lost to follow-up or who died during the period were excluded from the study as full details of health care expenses and income could not be established.

\section{Data collection and measurement}

A proforma was opened for each participant at the beginning of the study, and information about details of the participants 
was recorded therein. The residents were trained on how to fill the proforma. The proforma has sections on child's bio-demographic, parents occupation and educational attainments, family income, source of health financing, number of other household siblings, routine clinic check-up visits, and amount spent per visit for each child. Also, it has sections on illnesses and treatments given to each child with SCD as well as amount spent during each illness episode. These amounts included the hospital consultation fees, admission fees, and other user charges. If any drug or laboratory test was not available in the hospital after being prescribed by the doctor but was purchased or carried out outside the hospital, the receipts of payments for such drugs or tests were used to document their costs in the proforma. The cost of any drug or test not purchased or not done was not included as well as costs of treatments that were not received in our hospital, but these were acknowledged. The diagnoses of illnesses were made based on clinical information and laboratory tests where necessary, and the duration of hospital admission was calculated from admission to discharge for those admitted during the study. Any extra days spent in the hospital as a result of inability to pay hospital bill were discountenanced. Also excluded were the costs of transportation, foods, stipends for surrogate caregivers, and other inconsistent expenditures that are often not receipted. The household of each child was assigned into social class using the parents' occupation and educational levels. ${ }^{23}$

\section{Determination of health expenditure and family income}

The total health expenditure during the period $\left(\mathrm{HE}_{\mathrm{T}}\right)$ was computed by adding up all the expenditures made by households to maintain the health of each participating child. These included the addition of all expenses spent on routine clinic checks, hospital outpatient and inpatient treatments including laboratory investigations, and admissions. The monthly income of each household was determined by adding together all the income accruing to the households such as salaries, money realized from business engagements, gifts received in cash, and all other traceable sources of income. The total household (family) income during the period $\left(T_{\mathrm{FI}}\right)$ was computed by summing up all the monthly income of the households (addition of parents income).

\section{CHE determination}

Catastrophic expenditure estimation requires measuring the extent to which health expenditure exceeds different thresholds of household income or consumption expenditure. ${ }^{7,8,16}$
Studies have put the threshold for $\mathrm{CHE}$ at values exceeding $10 \%$ of the total household income or $40 \%$ of the household nonfood income. ${ }^{7,8,16}$ In this study, we used the former (health expenditure $>10 \%$ of total household income) to adjudge whether or not a household was involved in CHE while caring for their wards with SCD. Thus, percentage of the total household income spent as health expenditure on each child $\left(T_{\mathrm{HE} / \mathrm{FI}}\right)$ was calculated using the following equation.

$$
\begin{aligned}
& \text { Percentage income spent as } \\
& \text { health expenditure }\left(T_{\mathrm{HE} / \mathrm{FI}}\right)
\end{aligned}=\mathrm{HE}_{\mathrm{T}} / T_{\mathrm{FI}} \times 100
$$

where $\mathrm{HE}_{\mathrm{T}}$ is the total health expenditure during the study period and $T_{\mathrm{FI}}$ is the total household (family) income during the study period.

Any household with health expenditure proportion $\left(T_{\mathrm{HE} / \mathrm{FI}}\right)>10 \%$ was designated as being involved in $\mathrm{CHE}$ for the period of the study.

\section{Ethical approval}

The study was approved by the Ethics and Research Committee of the Ekiti State University Teaching Hospital, Ado Ekiti.

\section{Data analysis}

The data generated were entered into personal computer and analyzed using SPSS software version 18, and statistical significance was set at $P$-values $<0.05$.

\section{Results}

Only 111 children and their parents (households) completed the study out of the 122 children initially enrolled. One child died, while the remaining ten were either lost to follow-up or had inconsistent data and were excluded.

\section{Sociodemographic characteristics and households income}

The children comprised 64 (57.7\%) males and 47 (42.3\%) females. There was no more than one child participant per household, and the median number of other siblings in each of the patients' household was 3 (range: $1-5$ ). The study participants were aged between 15 and 180 months with a median age of 60 months. Fifty-seven (51.4\%), 46 (41.4\%), and eight (7.2\%) belonged to the lower, middle, and upper social classes, respectively. Only eight (7.2\%) were enrolled into the health insurance scheme (NHIS). The monthly family income of the households ranged from $\$ 12,500$ to $\$ 333,333$ (US\$76 to US\$2,020) with a median of $\$ 55,000$ (US\$333). Forty (36.0\%) households had 
their monthly income below the Nigerians' average national minimum wage of \$18,000 (US\$109) (Table 1).

\section{Treatment variables and associated comorbidities}

The median number of outpatients hospital visits was 4 (range: 1-10), and the amount paid by parents on each visit ranged between $\$ 650$ and $\$ 6,500$ (US\$4 and US\$39) with a median of $\$ 1,850$ (US\$11). In all, 88 (79.3\%) took ill during the study period, out of which $64(57.6 \%)$ required admission. In addition, 57 (51.4\%) also sought treatment at other places other than the study center, and some patients received treatments at multiple places for their illnesses. These places include orthodox faith-based centers (29, 50.9\%), patent medicine shops $(28,49.1 \%)$, traditional medicine $(14,24.6 \%)$, and other hospitals $(9,15.7 \%)$. The amounts spent at these facilities could not be substantiated and were not incorporated in the computed health expenditures in this study. For those admitted at our hospital, the number of admission episodes ranged between 1 and 5, while the admissions duration was between 1 and 11 days with an average of 4.23 days. The leading associated comorbid conditions for which the patients received treatments were malaria (60, $54.1 \%)$, vaso-occlusive crises $(58,52.2 \%)$, and severe anemia

Table I Characteristics of the children and their household income

\begin{tabular}{ll}
\hline Variable & $\begin{array}{l}\text { Total number of patients } \\
\mathbf{n}(\%)\end{array}$ \\
\hline Sex & $64(57.7)$ \\
Male & $47(42.3)$ \\
Female & \\
Age in months & $49(44.1)$ \\
I5-59 & $41(36.9)$ \\
$60-120$ & $21(19.0)$ \\
$>$ I20 & \\
Socioeconomic class & $8(7.2)$ \\
Upper & $46(41.4)$ \\
Middle & $57(51.4)$ \\
Lower & $8(7.2)$ \\
Enrolled on NHIS & $103(92.8)$ \\
Yes & \\
No & $21(19.0)$ \\
Household monthly income (Naira) & \\
$>$ a I00,000 & $42(37.8)$ \\
\#50,000-I00,000 & $48(43.2)$ \\
\#I2,500-49,999 & $40(36.0)$ \\
Households with earnings less than minimum wage \\
Less than national minimum wage
\end{tabular}

Notes: ${ }^{a}$ Exchange rate averaged at I 65 Naira $=$ I US dollar during the study. ${ }^{b}$ National minimum wage in Nigeria is $\$$ I 8,000 (US\$109). $\mathrm{N}=1$ I I.

Abbreviation: NHIS, National Health Insurance Scheme.
$(44,39.6 \%)$, and many of the patients were treated for more than one comorbid condition (Table 2).

\section{Health expenditures and their impacts on the households}

The total health expenditure of all the households was \#4,390,253.00 (US\$26,607.59) with a range between $\# 12,000$ and $\$ 215,000$ (US\$73 and US\$1,303), and a mean of $\$ 39,554 \pm 35,479$ (US\$240 \pm 215 ) per household, and hospital utilities bills and drugs constituted the bulk of the health expenses (Table 3 ). The percentage of family income spent on health care needs of each child was between $0.38 \%$ and $34.40 \%$ (mean $6.71 \pm 7.1$ ), and on the average, households on the lower social ladder spent higher proportion of their income on maintaining the health of their wards with SCD (Table 3). Amounts ranging between $\$ 5,000$ and $\$ 185,000$ (US\$30 and US\$1,121) were spent on each participant's illnesses needing admission during the period. Twenty-six (23.4\%) households took loans ranging between $\$ 6,500$ and $\# 150,000$ (US\$39 and US\$909) with a median of $\$ 28,750$ (US\$174) to offset hospital bills during the period. Parents of 63 (56.8\%) children lost between 1 and 48 working days as a result of taking care of the illnesses of the patients. Three parents lost their jobs due to their involvement in the care for their children and inability to attend work. The types of jobs lost included two private employments and one personal business.

\section{Relationships between variables and health expenditure}

The relationship between households' proportion, social class, monthly income, and health expenditure is shown in Table 4. Most households $(60,54.1 \%)$ spent $<5 \%$ of their income to maintain the health of the participants, but greater number of households in the lower class spent a greater proportion of their income to do this. Twenty-three $(20.7 \%)$ households were involved in CHE, and none of the households with CHE was on NHIS (Table 4).

Table 2 Associated comorbidities in the patients

\begin{tabular}{ll}
\hline Comorbidities & $\begin{array}{l}\text { Total number of patients } \\
\mathbf{n}(\%)\end{array}$ \\
\hline Malaria & $60(54.1)$ \\
Vaso-occlusive crisis & $58(52.3)$ \\
Severe anemia & $44(39.6)$ \\
Sepsis & $26(23.4)$ \\
Febrile convulsion & $4(3.6)$ \\
Food poisoning & $4(3.6)$ \\
Kerosene poisoning & $2(1.8)$ \\
Osteomyelitis & $2(1.8)$ \\
\hline Notes: Some patients had multiple comorbidities. N= 111.
\end{tabular}


Table 3 Health expenditures by categories of payment and social class

\begin{tabular}{|c|c|c|c|}
\hline Expenditure type & Range (mean \pm SD) (\#) & Total amount (\#) & $\begin{array}{l}\% \text { of total } \\
\text { health expenditure }\end{array}$ \\
\hline Laboratory tests & $342-36,765(6,739.38 \pm 6,087.00)$ & $748,071.10$ & 17.10 \\
\hline Drugs & $814-87,505(16,174.55 \pm \mid 4,396.06)$ & $\mathrm{I}, 795,375.70$ & 40.70 \\
\hline Hospital utilities ${ }^{a}$ & $844-90,730(16,637.89 \pm 15,016.29)$ & $\mathrm{I}, 846,806.20$ & 42.20 \\
\hline \multirow[t]{3}{*}{ Grand total of health expenditure } & $2,000-215,000(39,554.30 \pm 35,479.4 I)$ & $4,390,253.00$ & \\
\hline & Lower social class $(\mathbf{N}=\mathbf{5 7})$ & Middle social class $(\mathrm{N}=46)$ & Upper social class $(\mathbf{N}=\mathbf{8})$ \\
\hline & Range, \% (mean \pm SD) & Range, \% (mean \pm SD) & Range, \% (mean \pm SD) \\
\hline $\begin{array}{l}\text { Percentage of household income } \\
\text { spent on SCD child's health by } \\
\text { social class groups }\end{array}$ & $0.4 I-34.40(9.13 \pm 8.12)$ & $0.38-22.90(4.59 \pm 4.97)$ & $1.24-3.50(1.99 \pm 0.97)$ \\
\hline
\end{tabular}

Notes: aHospital utilities include hospital cost of admission, blood transfusion services, surgical operations, consumables, consultation fees, medical records, and nursing charges. Exchange rate averaged at I65 Naira =I US dollar during the study.

Abbreviations: SD, standard deviation; SCD, sickle cell disease.

\section{Predictors of $\mathrm{CHE}$}

Binary logistic regression analysis with the presence or absence of $\mathrm{CHE}$ as the dependent variable showed that households who had to take loan to offset hospital bills of their children (95\% confidence interval $[\mathrm{CI}] 5.4-87.1, P=0.000)$ belonged to lower social class ( $95 \%$ CI $2.3-47.3, P=0.002$ ), and whose children took ill requiring treatments during the study period ( $95 \%$ CI 1.1-29.7, $P=0.035$ ) were associated with higher odds for CHE (Table 5).

\section{Discussion}

Health care is a necessity and a basic human need. In recognition of this, the Alma Ata Declaration of 1978 stresses the need for various governments to put in place social guarantees that will ensure the health and other basic needs of their country's citizens. ${ }^{24}$

Table 4 Relationships between variables and health expenditures

\begin{tabular}{|c|c|c|c|}
\hline \multirow[t]{2}{*}{ Variable } & \multicolumn{3}{|c|}{$\begin{array}{l}\text { Family income spent on health } \\
\text { expenditure }\end{array}$} \\
\hline & $<\mathbf{5 \%}$ & $5 \%-10 \%$ & $>10 \%$ \\
\hline $\begin{array}{l}\text { Number of households } \\
n(\%)\end{array}$ & $60(54.1)$ & $28(25.2)$ & $23(20.7)^{\mathrm{a}}$ \\
\hline \multicolumn{4}{|c|}{ Number of households on NHIS, $n(\%)$} \\
\hline Yes & $8(7.2)$ & $0(0.0)$ & $0(0.0)$ \\
\hline No & $28(25.2)$ & $44(39.6)$ & $23(20.7)$ \\
\hline \multicolumn{4}{|l|}{ Social class, n (\%) } \\
\hline Upper class & $8(7.2)$ & $0(0.0)$ & $0(0.0)$ \\
\hline Middle class & $33(29.7)$ & $9(8.1)$ & $4(3.6)$ \\
\hline Lower class & $19(17.1)$ & $19(17.1)$ & $19(17.1)$ \\
\hline \multicolumn{4}{|c|}{ Monthly family income, n (\%) } \\
\hline$>\# 100,000$ & $21(18.9)$ & $0(0.0)$ & $0(0.0)$ \\
\hline$\# 50,000-100,000$ & $23(20.7)$ & $15(13.5)$ & $4(3.6)$ \\
\hline$\# 12,500-49,999$ & $16(14.4)$ & $13(11.7)$ & $19(17.1)$ \\
\hline
\end{tabular}

Notes: a Households with catastrophic health expenditure. Exchange rate averaged at I65 Naira = I US dollar during the study. $\mathrm{N}=$ I I I .

Abbreviation: NHIS, National Health Insurance Scheme.
In this study, $\sim 60 \%$ of the children with SCD were hospitalized. This affirms the observation by other authors that SCD exhibits a chronic course and that the disease condition usually results in many illnesses which often consume household resources. ${ }^{2,625-27}$ Several factors like illness perception, beliefs, and care opportunities affect the health-seeking behaviors of an individual. ${ }^{12,25}$ In addition to treatments received at the study center, a substantial proportion of the households also sought spiritual helps at both the orthodox and traditional faith-based centers. This highlights the beliefs of Nigerians regarding the use of such services as adjuncts to health care. ${ }^{12,28}$ This finding may also stem from the chronic nature of SCD necessitating the households to using every opportunity available to them to find relief from the disease burden..$^{12,25,28}$ Nevertheless, resources spent to procure these services often constitute additional financial burden to the households, and this could further impoverish them, given the observation

Table 5 Binary logistic regression for predictors of household catastrophic health expenditure

\begin{tabular}{|c|c|c|c|}
\hline Variables & OR & $95 \% \mathrm{Cl}$ & $P$-value \\
\hline \multicolumn{4}{|c|}{ Parents took loan to offset hospital bills } \\
\hline Yes & 21.694 & $5.399-87.176$ & 0.000 \\
\hline \multicolumn{4}{|l|}{ No } \\
\hline \multicolumn{4}{|l|}{ Social class } \\
\hline \multicolumn{4}{|l|}{ Upper } \\
\hline Lower & 10.481 & $2.322-47.310$ & 0.002 \\
\hline \multicolumn{4}{|c|}{ Patient took ill during the study period } \\
\hline Yes & 5.788 & I.I28-29.694 & 0.035 \\
\hline \multicolumn{4}{|l|}{ No } \\
\hline \multicolumn{4}{|c|}{ Household enrolled on NHIS } \\
\hline Yes & 2.131 & $0.101-44.803$ & 0.626 \\
\hline No & & & \\
\hline
\end{tabular}

Note: $P$-value in bold font indicates statistical significance.

Abbreviations: OR, odds ratio; $\mathrm{Cl}$, confidence interval; NHIS, National Health Insurance Scheme. 
that more than one-third of the households earn less than the national minimum wage in Nigeria (Table 1).

A look at the associated comorbid conditions (Table 2 ) in the patients further highlights the leading roles of malaria in the morbidity and mortality of children with SCD. ${ }^{3,29}$ It is interesting to note that the other two leading causes of morbidity in this study (vaso-occlusive crisis and severe anemia) could be linked to the complications of malaria. ${ }^{11,29}$ Malaria can lead to dehydration and acidosis, thus precipitating painful crises, while severe anemia is one of the hallmarks of complicated malaria. ${ }^{11,29}$ These vicious synergies raise the need for stakeholders to deploy all strategies to combating the menace of malaria and other associated comorbidities identified in these patients. Doing so will lead to reduction in illness episodes and cost of care.

More than $90 \%$ of the children were not on NHIS, while those enrolled only got partial subsidy. This observation affirms previous reports from Nigeria that between $70 \%$ and $100 \%$ of household health expenditures were financed through OOPS. ${ }^{6,7,10-13}$ Although similar scenarios have also been reported in other developing countries, ${ }^{8,14-16,30}$ the scenarios, as found in this study, sharply contrast with what is obtainable in most developed parts of the world. In these countries, health care expenses are mostly borne through prepayment methods through health insurance policies. ${ }^{8,14}$ OOPS does not offer any financial protection to households, prevents households from seeking health care, and may result in huge health expenditure that could lead to the impoverishment of households and/or push them into financial catastrophe..$^{8,14-16,30}$

In this study, 20.7\% households (Table 4) were involved in $\mathrm{CHE}$ indicating that they might have foregone other basic needs or become impoverished while taking care of their wards with SCD. There is the possibility that the proportion of households with CHE is likely to be more if the health care expenses of other members of the households, as well as expenses incurred at other places where caregivers sought care for their wards with SCD, were accounted for. Apart from loss of business, parents of 63 children also lost productive time (working days) to their wards' illnesses.

Despite these dilution factors, and the focus of this study on only childhood SCD-related illnesses, the proportion of CHE recorded is relatively high compared to $2.9 \%, 15 \%$, and $15.5 \%$ reported for the care of all household illnesses in Uganda, ${ }^{31}$ Burkina Faso, ${ }^{32}$ and Kenya, ${ }^{16}$ respectively. Interestingly, all of them are fellow African countries. The rate of $\mathrm{CHE}$ in this study is also very high when compared to the $0.6 \%-3 \%$ range reported from some Latin American countries. ${ }^{14}$ That SCD solely accounted for the huge financial burden in this study is not surprising. Studies from the USA indicate that the disease condition often leads to greater financial expenses on households. ${ }^{26,27}$ These observations point to the high burden and enormous financial challenges households in the study area faced while taking care of their wards with SCD illness. A child with SCD often requires frequent hospital visits for the treatment of chronic illnesses necessitating households to bear financial costs.

Households or individuals often derived various strategies to cope with huge health expenditure, some of which include forsaking other basic needs, taking loans, or selling off assets or personal belongings among other things to defray their huge health expenditure..$^{6-8,11-16}$ Households in our series only took loans, and this was done by $23.4 \%$ of them. A look at these loans indicates that they were more than the average national minimum wage in Nigeria in most instances. ${ }^{21}$ Another distressing fact is the observation that households involved in this were 20 times more at risk of CHE when compared to others who did not borrow to pay for their wards' health expenses (Table 5). The situation as found in this study could further lead to the possibility of financial emasculation of the households and/or push them into poverty. In the developed world, government has mechanisms to prevent households from huge health expenditure, and most of the mechanisms revolve around increased government investments in health care needs of their citizens. ${ }^{9,14-17,33}$ Regrettably, government expenditure on health in Nigeria and other Sub-Saharan Africa has been inadequate and inequitable. ${ }^{9,33}$

The poor level of government public health expenditure is more precarious in Nigeria compared to her African neighbors. ${ }^{33}$ In 2010, the Nigerian government spent only $4.4 \%$ of the total budget on health. ${ }^{33}$ This figure represents a paltry $5.3 \%$ of the country's gross domestic products (GDPs) for the period compared to $6.7 \%$ and $7.9 \%$ of the GDPs in Burkina Faso and Democratic Republic of Congo spent by the governments of these countries on public health over the same period. More worrisome is the fact that these countries have lower GDPs compared to Nigeria. ${ }^{33}$ The situation as found in Nigeria negates the spirit of the April 2001 Abuja declaration by all African Union (AU) members. In that famous declaration, all AU members pledged that no $<15 \%$ of their annual budgets will be dedicated to health funding. ${ }^{34}$ Hence, the situation on CHE as obtainable in the study area could be a reflection of inadequate investments in the health sector, and this may not allow for universal health coverage (UHC) for individual households with SCD as well as other citizens of the country. UHC is defined as provision of access 
to health care and financial protection for all. Currently, only $6 \%$ of households in Nigeria have achieved UHC. ${ }^{33}$

\section{Way forward}

There is need to focus on strategies that will reduce the prevalence of SCD as well as the burden of health care cost in the study area. For the strategies to be successful, they must take into consideration that the bulk of Nigerians reside in the rural areas, and as such, the primary health care could be a good avenue to deliver most of them. ${ }^{3}$ The following approaches will be very useful among other methods.

a. Massive awareness and education campaign: This should involve giving information about mode of inheritance of the disease, well-informed premarital counseling, and testing. Such campaigns should involve all stakeholders including the media, political class, traditional rulers, market women groups, religious leaders, sports and other celebrities, and health care providers. Information on sickle cell disorders could also be incorporated into the basic education curriculum in Nigeria which is presently free in the country and have the advantage of reaching a large target population. Doing these will reduce the ignorance and poor attitude of some Nigerians toward children with SCD. ${ }^{35}$

b. Early diagnosis: This approach has greatly improved the outcome of children with SCD in the USA and has been recommended for other countries lately. ${ }^{36}$ This can be achieved through universal newborn screening. ${ }^{3,36}$ The concept has also been supported in Nigeria by the newly formed body (The Nigerian Sickle Cell Disease Network), an umbrella body of physicians, and nongovernmental organizations interested in the care of individuals with SCD in Nigeria. ${ }^{3}$ Stakeholders should scale up facilities for universal newborn screening in the country. Doing so will allow for early diagnosis and better outcome for the patients.

c. Strategies to reduce disease severity: As observed in this study, households whose wards took ill during the study period were more involved in CHE. Hence, prevention of malaria, and bacterial and other infections that are leading comorbidities in this study is desirable. This could be done through the use of cost-saving measures like environmental and personal hygiene, malaria and pneumococcal vaccination, and chemoprophylaxis. ${ }^{3}$ A recent study from Nigeria indicates that the uptake of pneumococcal vaccines by caregivers was influenced by household income and that low-income households were unwilling to partake. ${ }^{37}$ Recently, the Nigerian government has started a stepwise incorporation of pneumococcal and other new vaccines into the immunization program. Scaling up the new National Programme on Immunisation would offset more burden on parents.

d. Protection against catastrophic and huge health expenditure: Having an health insurance provides security for households and protect them from financial burden. ${ }^{33}$ There is need to scale up current status of enrollment into the health insurance scheme in Nigeria and incorporate other community insurance models that have worked in the country. ${ }^{33}$ In addition, government must gear up efforts at encouraging funding from both local and international bodies. Recent statistics indicate that other African neighbors are getting more funds from donor bodies to finance their health sector. For example, in 2010 , up to $17 \%$ of Ghana's health funding came through foreign donations as against Nigeria's $9 \%$ in the same year. ${ }^{38}$ Removing all barriers or factors that make foreign donors disinterested in funding the Nigeria health sector is recommended. In addition, all legal instruments that will improve health care funding in Nigeria should be activated. A good example is the new Nigerian National Health Bill. ${ }^{39}$ Under the new act, there is provision for free treatment for all under-five children. Also, there is provision for constant availability of fund for the health sector as $1 \%$ of the country's consolidated revenue has been dedicated as Basic Health Provision Fund and 50\% of this fund is to be channeled to make NHIS better positioned for more households enrollment. The remaining $50 \%$ is to be channeled to the primary health care and other health care needs including recognition of non communicable diseases like SCD. ${ }^{39}$ Relevant authorities should quickly move to implement the contents of the bill so that parents will no longer incur huge health expenditures while caring for their wards as observed in this study.

\section{Conclusion}

This study has highlighted the huge financial burden households face while taking care of their wards with SCD. The study also highlighted various approaches to mitigating this huge economic burden. One key approach that seems promising is the implementation of the newly passed Nigerian National Health Bill across board among other measures.

\section{Limitations}

This study is limited by its being hospital based and might have therefore underestimated the burden of SCD care on households in the study locality. It might have also excluded 
some patients who were having mild SCD manifestations and who did not visit during the period of the study or who were receiving treatments at lower levels of care because of their mild disease. Nevertheless, in the data-poor setting of the study, hospital-based studies are commonly the most reliable, and sometimes, the only source of realistic data.

We were unable to measure indirect costs of illness, such as loss of productive time and earnings by parents, and cost of feeding and transportation, while caring for their child's illnesses. Also, the cost of care accessed in other health care facilities during the period of study could not be accounted for. These are recommended areas for future research.

\section{Acknowledgment}

The authors appreciate the parents of their study participants for their cooperation.

\section{Author contributions}

OSO conceived the study, managed the patients, supervised data collection, and drafted the manuscript. All authors contributed toward data analysis, drafting and critically revising the paper and agree to be accountable for all aspects of the work.

\section{Disclosure}

The authors report no conflicts of interest in this work.

\section{References}

1. World Health Organisation. Fifty ninth World Health Assembly Sickle Cell Anaemia-report by the secretariat provisional agenda 2006;11:4 items. Available from: http://www.who.int/pdf files/WHA59/A59_9-en. pdf. Accessed March 10, 2015.

2. Sadarangani M, Makani J, Komba AN, et al. An observational study of children with sickle cell disease in Kilifi, Kenya. Br J Haematol. 2009;146:675-682.

3. Galadanci N, Wudil BJ, Balogun TM, et al. Current sickle cell disease management practices in Nigeria. Int Health. 2013;6(1):23-28.

4. Bhagat VM, Baviskar SR, Mudey AB, Goyal RC. Poor health related quality of life among patients of sickle cell disease. Indian J Palliat Care. 2014;20:107-111.

5. Brown BJ, Jacob NE, Lagunju IA, Jarett OO. Morbidity and mortality pattern in hospitalised children with sickle cell disorders at the $\mathrm{UCH}$ Ibadan, Nigeria. Niger J Paediatr. 2013;40(1):34-39.

6. Brown BJ, Okereke JO, Lagunju IA, Orimadegun AE, Ohaeri JU, Akinyinka OO. Burden of health-care on carers of children with sickle cell disease in Nigeria. Health Soc Care Community. 2010;18(3): 289-295.

7. Ekwochi U, Osuorah DC, Ndu IK, Ezenwosu OU, Amadi OF, Odetunde OI. Out-of-pocket cost of managing sick newborns in Enugu, Southeast Nigeria. Clinicoecon Outcomes Res. 2014;6:29-35.

8. Xu K, Evans DB, Kawabata K, Zeramdini R, Klavus J, Murray CJ. Household catastrophic health expenditure: a multicountry analysis. Lancet. 2003;362:111-117.

9. The World Databank. Poverty Level and Inequality Database 2010. Available from: http://www.brookings.edu/researchpapers/2013/06/ achieving-universal-health-coverage-nigeria. Accessed January 10, 2015 .
10. Sambo MN, Ejembi CL, Adamu YM, Aliyu AA. Out-of-pocket health expenditure for under five illnesses in a semi-urban community in Northern Nigeria. J Community Med Prim Health Care. 2004;16(1):29-32.

11. Onwujekwe O, Uguru N, Etiaba E, Chikezie I, Uzochukwu B, Adjagba A. The economic burden of malaria on households and the health system in Enugu State Southeast Nigeria. PLoS One. 2013;8(11):e78362.

12. Bamidele MA, Adams S, Adejumo AO. Out of pocket health care spending among households in Keffi, Nigeria. Health Sci Res. 2014;1(4):72-77.

13. Tongo OO, Orimadegun AE, Ajayi SO, Akinyinka OO. The economic burden of preterm low birth weight care in Nigeria. $J$ Trop Pediatr. 2009;55:262-264.

14. Xu K, Evans DB, Carrin G, Aguilar-Rivera AM, Musgrove P, Evans T. Protecting households from catastrophic health spending. Health Aff. 2007;26(4):972-983.

15. Gotsade G, Zoidze A, Rukhadze N. Household catastrophic health expenditure: evidence from Georgia and its policy implications. $B M C$ Health Serv Res. 2009;9:69.

16. Chuma J, Maina T. Catastrophic health care spending and impoverishment in Kenya. BMC Health Serv Res. 2012;12:413.

17. O'Donnell O, Van Doorslaer E, Wagstaff A, Lindelow M. Analysing Health Equity Using Household Survey Data: A Guide to Techniques and Their Implementation. Washington, DC: The World Bank; 2008.

18. Legal notice on publication of 2006 census final results if the Federal Republic of Nigeria, 2006 National Population Census official Gazette. Annexure A, B and C 2009;96(2):B1-B42. Available from: http://www. placng.org/legal/Notice on 2006 census final results. Accessed February 20, 2015.

19. The Official Website of Ekiti State Government. Available from: http:// www.ekitistate.gov.ng. Accessed September 5, 2015.

20. National Health Insurance Scheme (NHIS) in Nigeria. Available from: http://nhis.gov.ng. Accessed January 12, 2015.

21. National Minimum Wage Act 2011 (Nigeria) Explanatory memorandum Available from http://www.nassnig.org/document. Accessed March 31, 2015.

22. The Naira Exchange Rate. Available from: http://www.xe.com. Accessed December 26, 2014.

23. Oyedeji GA. Socioeconomic and cultural background of hospitalised children in Ilesa. Niger J Paediattr. 1985;13:111-117.

24. Declaration of Alma-Ata September 12, 1978. Available from: http:// www.who.int. Accessed March 14, 2015.

25. Anie KA, Egunjobi FE, Akinyanju OO. Psychosocial impact of sickle cell disorders: perspectives from a Nigerian setting. Glob Health. 2010;6(2):1-6.

26. Mvundura M, Amendah D, Kavanagh PL, Sprinz PG, Grosse SD. Health care utilization and expenditures for privately and publicly insured children with sickle cell disease in the United States. Paediatr Blood Cancer. 2009;53(4):642-646.

27. Amendah D, Mvundura M, Kavangh PL, Sprinz PG, Grosse SD. Sickle cell disease related paediatric medical expenditures in the US. Am J Prev Med. 2010;38(4):S550-S556.

28. Adanikin AI, Onwudiegwu U, Akintayo AA. Reshaping maternal services in Nigeria: any need for spiritual care? BMC Pregnancy Childbirth. 2014;14:196.

29. McAuley CF, Webb C, Makani J, et al. High mortality from Plasmodium falciparum malaria in children with sickle cell anaemia on the cost of Kenya. Blood. 2010;116:1663-1668.

30. Leive A, Xu K. Coping with out-of-pocket health payments: empirical evidence from 15 African countries. Bull World Health Organ. 2008;86(11):849-856.

31. Xu K, Evans DB, Kadama P, et al. Understanding the impact of eliminating user fees: utilization and catastrophic health expenditures in Uganda. Soc Sci Med. 2006;62:866-876.

32. Su TT, Kouyate B, Flessa S. Catastrophic health expenditure for health care in a low-income society: a study from Nouna District Burkina Faso. Bull World Health Organ. 2006;84:21-27. 
33. Gutstafsson-Wright E, Schellekens O. Achieving Universal Health Coverage in Nigeria one state at a time: a public-private partnership community based health insurance model. Brooke Shearer Working Paper Series 2 June 2013;1-28 Available from: http://www.brookings. edu_media/research. Accessed March 12, 2015.

34. WHO. The Abuja Declaration: Ten Years On. Available from: http://www. who.int/healthsystem/publications/Abuja10.pdf. Accessed March 10, 2015.

35. Afolayan JA, Jolayemi FT. Parental attitude to children with sickle cell disease in selected facilities in Irepodun Local Government Kwara State, Nigeria. Etno Med. 2011;5(1):33-40.
36. Wang CJ, Kavangh PL, Little AA, Holliman JB, Sprinz PG. Quality of care indicators for children with sickle cell disease. Paediatrics. 2011;128:484-493.

37. Roberts AA, Izuka MI, Ekanem EE, Mabogunje CA. Predictors of pneumococcal immunisation uptake among caregivers of children with sickle cell disorders in Lagos, Nigeria. J Public Health Epidemiol. 2013; 5(12):488-492.

38. WHO. Global Health Observatory Data Repository 2011. Available from: http://www.int/gho/data/node.main. Accessed March 12, 2015.

39. The Nigeria National Health Bill 2014. Available from: http://www nigeriahealthwatch.com. Accessed March 10, 2015.

\section{Publish your work in this journal}

ClinicoEconomics \& Outcomes Research is an international, peerreviewed open-access journal focusing on Health Technology Assessment, Pharmacoeconomics and Outcomes Research in the areas of diagnosis, medical devices, and clinical, surgical and pharmacological intervention. The economic impact of health policy and health systems organization also constitute important areas of coverage. The manuscript management system is completely online and includes a very quick and fair peer-review system, which is all easy to use. Visit http://www.dovepress.com/testimonials.php to read real quotes from published authors.

Submit your manuscript here: http://www.dovepress.com/clinicoeconomics-and-outcomes-research-journal 